\title{
Antikoagulační terapie dabigatranem vs rivaroxabanem u seniorů ve věku nad 65 let: porovnáni dat "head to head“"
}

\author{
Martin Polák \\ JIP internich oborů Interního oddělení Oblastní nemocnice Př́bram, a.s.
}

Fibrilace síní (FS) je nejčastější setrvalou poruchou rytmu, jejíž prevalence se pohybuje kolem $3 \%$ ve věku > 20 let, s přibývající prevalencí ve starší populaci. Odhaduje se, že v EU má FS přibližně 20,9 milionů mužů a 12,6 milionů žen. Předpokládá se, že do roku 2030 vzroste počet pacientů s FS v EU na 14-17 milionů, přičemž každoročně bude FS nově diagnostikována u 120 000-215 000 pacientů. Důležitost problematiky FS v ČR se stárnutím populace ukazuje fakt, že v roce 2030 bude ČR v počtu seniorů na 2. místě v Evropě. Závažnost FS dokreslují data o mortalitě a riziku vzniku iktu. $V$ managementu FS jsou důležité zejména 4 oblasti - léčení příznaků, kontrola srdeční frekvence - "rate control“, kontrola rytmu - „rhythm control“ a prevence trombotických príhod, především iktu, pomocí antikoagulační terapie. Doporučené postupy pro antikoagulační terapii jsou formulovány $v$ dokumentu České kardiologické společnosti (ČKS) z roku 2016, který vznikl na základě Doporučených postupů ESC 2016 pro léčbu fibrilace síní $[1,2]$.

Žijeme $v$ éře, kdy nejsme již odkázáni jen na použití antagonistů vitaminu K (VKA), tedy warfarin, ale můžeme použit i nová antikoagulancia (NOAC), mezi která patř́ přímý inhibitor trombinu dabigatran a inhibitory faktoru Xa apixaban, rivaroxaban a edoxaban. Při volbě vhodného antikoagulancia se rí́díme podle růz- ných kritérií, přičemž základem je $\mathrm{CHA}_{2} \mathrm{DS}_{2}$-VASc skóre, HAS-BLED skóre, SAMeTT $\mathrm{R}_{2}$ skóre, musíme ale vycházet i z dalších faktorů, jako je hodnota clearance kreatininu apod.

Mezi nejčastěji užívané léky patří dabigatran a rivaroxaban. Jejich uvedení do praxe umožnily klinické studie RE-LY (dabigatran) a ROCKET-AF (rivaroxaban). $\checkmark$ praxi jsou však velmi důležitá tzv. tvrdá data z reálné praxe. Hodnotíme nejenom efektivnost léčby či prevence antikoagulační léčby, ale také výskyt nežádoucích účinků této léčby, především výskyt závažného krvácení, a to intrakraniálního či gastrointestinálního. Mezi obzvláště rizikovou skupinu patří skupina seniorů ve věku $>65$ let.

Hodnocení NOAC ve vztahu kVKA je dostatečně známé. Porovnání NOAC mezi sebou navzájem je podstatně složitější. „Head to head“ porovnání dabigatranu a rivaroxabanu bylo provedeno na základě retrospektivní kohortové studie Grahama et al z FDA v USA u nových uživatelů antikoagulačních látek, kteří začali užívat jednu z uvedených látek od listopadu roku 2011 do 30. června 2014, analýza dat byla provedena v období od 7. 5. 2015 do 30. 6. 2016 [3]. Cílem retrospektivní nerandomizované studie bylo porovnat rizika tromboembolických príhod (TEN), intrakraniálního krvácení (ICH), velkých extrakraniálních krvá-

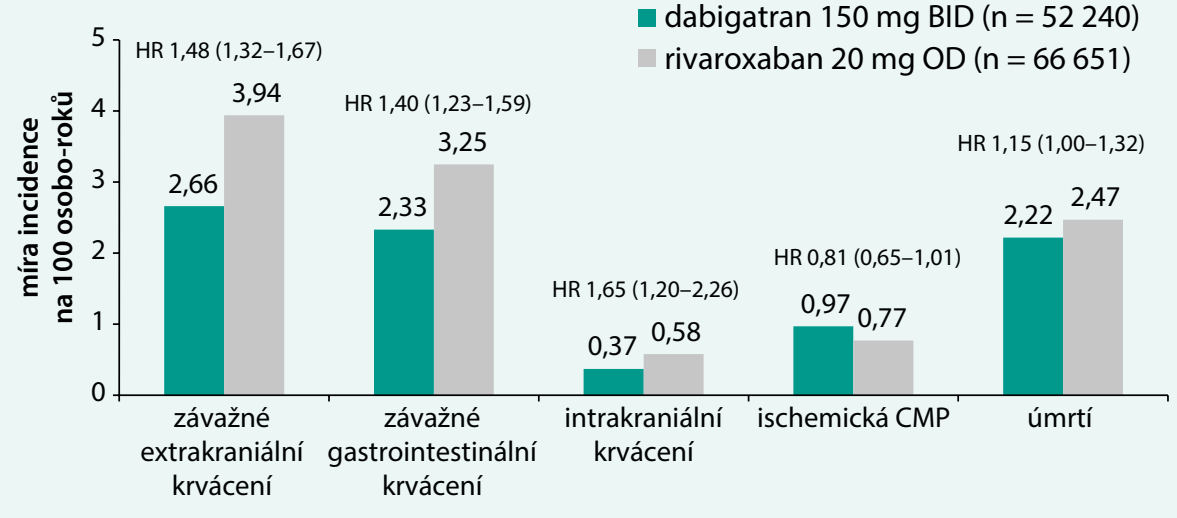


cení a mortalitu u pacientů s nevalvulární FS, kteří užívají dabigatran nebo rivaroxaban v prevenci ischemické CMP. Kohortová studie hodnotila celkem 118891 pacientů s nevalvulární FS ve věku > 65 let, a to 52240 pacientů léčených dabigatranem v dávce $2 \mathrm{krát} 150 \mathrm{mg}$ a 66651 pacientů léčených rivaroxabanem v dávce 1krát 20 mg (47 \% žen). Ve $100 \%$ se jednalo o pacienty warfarin-naivní. Během sledovaného období se objevilo 2537 príhod posuzovaných jako primární end-point. Jako statistická metoda, která ukazuje, jakou roli hrají korelované proměnné při odhadování účinku rizikových faktorů, byla využita analýza pomocí propensity skóre. Výsledkem hodnocení je, že užívání rivaroxabanu je ve srovnání s užíváním dabigatranu spojeno se statisticky nesignifikantním snížením rizika vzniku iktu (HR 0,81; $95 \% \mathrm{Cl} 0,65-1,01 ; \mathrm{p}=0,07)$, statisticky signifikantním zvýšením rizika vzniku intrakraniálního krvácení (HR 1,65; 95\% Cl 1,20-2,26; $p<0,001)$, statisticky signifikantním zvýšením rizika extrakraniálního krvácení (HR 1,48; 95\% Cl 1,32-1,67; $\mathrm{p}<0,001)$, včetně krvácení do gastrointestinálního traktu (HR 1,40; 95\% Cl 1,23-1,59). Výsledky shrnuje graf.

Pravděpodobně je s užíváním rivaroxabanu u seniorů spojena i vyšší mortalita. Počet př́hod intrakraniálního krvácení v souvislosti s užíáním rivaroxabanu eliminoval snížení rizika vzniku iktu. Vyšší antikoagulační efekt pozorovaný u rivaroxabanu může být způsoben vyšší dávkou podávanou 1 krát denně, nemůže být vyloučeno ani off-label použití rivaroxabanu u pacientů se zhoršenou funkcí ledvin.

Uvedená retrospektivní studie má celou řadu limitací, u mladších pacientů mohou být výsledky odlišné. Výsledky by se mohly lišit i u pacientů, u nichž byla změněna terapie VKA na terapii NOAC.

\section{Závěry}

Uvedená retrospektivní studie je novým milníkem v éře výzkumu NOAC: mezi sebou jsou porovnávány jednotlivé látky $z$ této skupiny. $V$ našem konkrétním prípadě se ukazuje, že by dabigatran ve srovnání s rivaroxabanem měl být preferenčně užíván u pacientů ve věku $>65$ let, a to $z$ důvodu vyšší bezpečnosti i většího snížení rizika vzniku iktu u pacientů s nevalvulární FS. Bezpečnost užívání dabigatranu umocňuje i skutečnost, že v Evropě (a tedy i v ČR) Ize u starších pacientů ve věku $>80$ let podávat dabigatran v nižší dávce 2 krát 110 mg a existence specifického antidota idarucizumabu.

\section{Literatura}

1. Čihák $R$, Haman L, Táborský $M$ et al. Doporučené postupy ESC 2016 pro léčbu fibrilace síní formulované ve spolupráci s EACTS. Cor et vasa 2016; 58(6): 728-771.

2. Kirchhof P, Benussi S, Kotecha D et al. 2016 ESC Guidelines for the Management of Atrial Fibrillation dveloped in Collaboration with EACTS. Europace 2016; 18(11): 1609-1678.

3. Graham DJ, Reichman ME, Wernecke M et al. Stroke, Bleeding, and Mortality Risks in Elderly Medicare Beneficiaries Treated With Dabigatran or Rivaroxaban for Nonvalvular Atrial Fibrillation. JAMA Intern Med 2016; 176(11): 1662-1671.

4. Schaefer JK, McBane RD, Wysokinski WE. How to Choose Appropriate Direct Oral Anticoagulant for Patient with Nonvalvular Atrial Fibrillation. Ann Hematom 2016; 95(3): 437-449.

5. Shenasa M, Camm JA. Management of Atrial Fibrillation. Oxford University Press: Oxford 2015. ISBN 978-0-19-968631-5.

\section{MUDr. Martin Polák \\ $\triangle$ martin.polak@onp.cz}

JIP interních oborů Oblastní nemocnice Příbram, a.s. www.onp.cz

Doručené do redakce 21. 3. 2017 